\title{
Tasa-arvotavoitteesta aikuiskoulutuksen suunnittelussa
}

Aikuiskoulutuksen johtoryhmä on tuottanut muistion nimeltä "Tasa-arvo aikuiskoulutuksen suunnittelun periaatteena". Muistio on tarkoitettu aikuiskoulutuksen kehittämistyössä mukana oleville eri osaprojekteille pohjapaperiksi, kun projektit kukin tahoillaan suunnittelevat toimenpiteitä koulutuksellisen tasaarvon lisäämiseksi.

Aikuiskoulutuksen johtoryhmä ei kuitenkaan ole antanut keskeiselle tasa-arvokäsitteelle täsmällistä sisältöä tai edes "suositusta koulutuksellisen tasa-arvon lisäämiseksi", vaan siirtänyt määrittelyn myöhempään ajankohtaan.

Muistiosta ei käynyt selväksi, onko johtoryhmässä varsinaisena ongelmana ollut itse sa$n a$ tasa-arvo ja sen herättämät abstraktit, tunnepitoiset mielleyhtymät, vai itse asia; yksimielisyyteen pääsy käsitteen sisällöstä sovittaessa.

Muistiossa esitetään tasa-arvokäsitteelle (sanalle?) synonyymeiksi "tasa-vertaisuutta", "yhdenvertaisuutta" ja "koulutuksellista oikeudenmukaisuutta". Miten muuten olisi yksi rinnastus lisää: samanarvoisuus? Tasa-arvokäsitteen (sanan?) vastakohdaksi on muistiossa nimittäin valittu käsite (sana?) eriarvoisuus kielellisistä eikä esimerkiksi käsitteellisistä syistä.

Muistiosta on, ainakin aikuiskoulutuksen kehittämisorganisaation ulkopuolisen, mutta tasa-arvon parissa päivittäin työskentelevän, vaikea saada otetta. Mukana tuntuu olevan aineksia lähes kaikista eettisestä, ymmärtävästä ja sallivasta ajattelusta, mitä kaiken mahdollisen hyvän toteutumiseksi voisi ajatella - myös maininnat sukupuolten tasa-arvosta!

\section{Liittyykö koulutuksellisen tasa-arvon edistämiseen ei-toivottujakin piirteitä?}

Tavallisessa elämässä, tulevaisuuden suunnittelussa jne. on ehkä helpompi määritellä, mitä ei missään nimessä halua, kuin mitä täsmällisesti haluaa tai toivoo. Miksi ei näin voitaisi menetellä myös niinkin ihmisläheisessä ja konkreettisessa asiassa kuin aikuiskoulutuksen suunnittelussa - edes toistuvien väärinymmärrysten välttämiseksi. Otanpa esiin pari esimerkkiä.

Peruskoulu-uudistuksen yhteydessä yläasteiden tasokurssijärjestelmää puolustettiin $\mathrm{mm}$. sillä, että kurssittoman "tasa-arvojärjestelmän" pelättiin tasapäistävän kasvavan sukupolven. - Ja tasapäistävän nimenomaan tulevat kansankynttilät keskinkertaisuuden harmaaseen massaan.

Tunteisiin vetoava tasapäistämispelko, kuten sivusta asiaa seuraavista saattoi näyttää, siirsi rinnakkaiskoulujärjestelmän peruskouluun. Nyttemmin tasokursseista ollaan luopumassa, ei tosin yleisen tasa-arvon nimissä vaan siksi, että järjestelmä tuotti naisylioppilaita kaksi kertaa enemmän kuin miesylioppilaita.

Keskusteluun sukupuolten tasa-arvosta liittyy aina myös henkilökohtaisia tunteita ja asenteita. Vieläkin törmää päivittäin enemmän tai vähemmän pelkoon, että sukupuolten tasa-arvo tuhoaa sukupuolisen kyvykkyyden, seksuaalisen vetovoiman tai eroottisuuden.

Tasa-arvo siis samanlaistaisi naiset ja miehet. Pelon takana on toisaalta perinteiseen miehenrooliin sisäistynyt näkemys, jossa miehisyyteen on samastunut ylemmyyden tunne naista kohtaan. Toisaalta naisenrooliin on sisäistynyt näkemys, jossa naisellisuus elää sopusoinnussa luopumisen ja alistumisen kanssa. Todellisuudessa lisääntyvä henkinen samanarvoisuus naisen ja miehen välillä tuskin samanlaistaisi tai latistaisi elämää, koska mm. "'keksijöitä" vapautuisi lisää.

Onko aikuiskoulutuksen tasa-arvotavoitteella pelottavia myyttejä? Tasapäistäminen, yhdenmukaistaminen, "ylhäältä" yhteiskunnasta tuleva aikuiskoulutusvaatimus, aikuisten häirintä? Vaikka tällaisten tasa-arvopeikkojen esiin manaaminen saattaa tuntua liian yksinkertaiselta suunnittelijoista itsestään, olisi näiden peikkojen yksiselitteinen tunnistaminen ja torjuminen jo varhaisessa vaiheessa ollut perusteltua: suunnittelu konkretisoituisi, ennakkoluulot vähenisivät, mahdollisissa erimielisyyksissä olisi kyse erimielisyyksistä, eikä erilaisista mielleyhtymistä samassa asiassa. 


\section{Ihminen - yhteiskunta}

Muistio ei käsittele suoraan tasa-arvotavoitteiden tiellä olevia ennakkoluuloja, mutta tekee eräitä valintoja ja rajauksia, ikään kuin niitä olisi olemassa.

Tasa-arvosisältöisen suunnittelun lähtökohdaksi on valittu yksilö sekä yksilön omat arvojärjestelmät ja normistot. Nämä puolestaan "saavat olla ristiriidassa yhteiskunnan vastaavien järjestelmien kanssa". Hyvä! Aikuiseen suhtaudutaan siis aikuisena! - Rajatta?

Tasa-arvokäsite on myös sidottu tietoiseen toimintaan siten, että yksilöä voidaan pitää tasa-arvoisena muihin nähden, kun tämä tekee tietoisia valintoja koulutuksessaan, olivatpa ratkaisut mitä tahansa. Entä sitten suhtautuminen aikuiskoulutukseen yhteiskunnallisesti hyväksyttynä ajanviettotapana tai elämän muotona, joka ei sisällä tietoisia valintoja?

Yksilökohtaisuus on valittu vastakohtana yhteiskunnan arvojärjestelmästä ja normistosta lähtevälle suunnittelulle. Muistiossa yhteiskunnan lähtökohta samastetaan ulkokohtaisuuteen ja jonkinlaiseen yhteiskunnan hyötyyn, joka ei ole ottanut huomioon vähiten koulutettujen ja "passiivisten" ihmisten tarpeita. Ikään kuin meillä siis olisi olemassa jokin yksimielinen, yksiselitteinen ja yksilöä rajoittava näkemys yhteiskunnasta. - Yhteiskunnassa vaikutusvallasta kilpailevat todellisuudessa monet erilaiset intressiryhmät ja arvostukset.

Muualla muistiossa, esimerkiksi toimenpiteiden kohdentamisosassa, yhteiskunta on käsitetty demokraattiseksi ja sellaiseksi, jossa ei eettisesti voida hyväksyä sivistyksellisten ja aineellisten etujen ohjautumista pelkästään hyvässä asemassa oleville. Sellainen yhteiskunta ei myöskään voi olla pelottava! Sellainen yhteiskunta on jäsentensä yhteiskunta ja tasaarvoinen. Mikä on siis todella johtoryhmän käsitys yksilöstä ja yhteiskunnasta?

Puutuin tähän yksilö-yhteiskunta -kysymykseen siksi, että se on tasa-arvoproblematiikassa varsin oleellinen. Käsiteltävänä olevassa muistiossa on käsite yhteiskunta nähty mielestäni yksioikoisesti asettamalla se yksilön vastakohdaksi. On muistettava, että johtoryhmänkin paperi edustaa yhteiskunnan näkemystä, sillä se on asetettu yhteiskunnan (tässä: opetusministeriön) toimesta. Voiko muistion sanomaan, että se asettuu kuitenkin kunnioittamaan yksilöjäseniään ja kantamaan huolta vähiten koulutusta saaneista, siis luottaa?

Käsitteiden sisällöstä sopiminen tavalla, joka olisi karsinut myyttejä, lisännyt yksiselitteisyyttä, mutta tarjonnut käytännöllisiä vaih- toehtoja, olisi ollut tasa-arvoa edistävä toimenpide suunnittelussa.

\section{Tasa-arvo kehittämis- organisaation suunnittelutyössä}

Tasa-arvo on muistionkin mukaan moniulotteinen käsite ja tasa-arvotavoitteiden toteuttaminen edellyttää useita samanaikaisia toimenpiteitä. Sukupuolten tasa-arvon edistämisessä, joka on myös aikuiskoulutuksen eräs tehtävä, on nähty esimerkiksi seuraavien kolmen näkökulman liittyvän toisiinsa:

\section{Laadullinen tasa-arvo,}

jolla tarkoitetaan eri väestöryhmien, kulttuurien, intressiryhmien sekä naisten ja miesten (joita kumpiakin on useimmissa ryhmissä) arvostusten, tarpeiden, kokemusten jne samanarvoisuutta. Osoitus eri ryhmien ja arvojen samanarvoisuudesta näkyy käytännössä myös

2. edustuksellisen tasa-arvon turvaamisena. Toisin sanoen asianomaisia koskevassa valmistelutyössä, päätöksenteossa sekä arvostusten ja normistojen kehittämistoiminnassa tulisi eri tahojen olla edustettuina. Toistaiseksi meillä onkin hyväksytty edustuksellisuus poliittisessa, alueellisessa tms. mielessä, mutta ei esim. sukupuolten samanarvoisuutena. Vasta edustuksellinen tasa-arvo tekee eri elimistä asiantuntevan suunnittelemaan, ratkaisemaan ja hienosäätämään

3. tasa-arvoa edistäviä toimenpiteitä, sillä samaan tulokseen pääsy (esim. tietoisia valintoja tekevät, luovat yksilöt) edellyttää eri väestöryhmissä erilaisia toimenpiteitä. Tasa-arvoa edistävillä toimenpiteillä tarkoitetaan syrjityssä ja huonoimmassa asemassa olevien aseman parantamista (ei jo ennestään aktiivisten ja luovien toiminnan sammuttamista). Tasa-arvoajattelun taustalla on myönteinen ihmiskuva: naapurin hyvinvointi lisää minunkin hyvinvointiani.

Muistiossa on tunnistettu ainakin viimeksi ja osittain myös ensinmainittu tasa-arvonäkökulma. Näkökulmat ovat kuitenkin jääneet melko abstrakteiksi, koska niitä yhdistävä ja niiden edellytyksenä oleva edustuksellinen tasa-arvotavoite organisaatioissa on jäänyt oivaltamatta (aikuisten osallistumista henkilökohtaista koulutustaan koskevaan suunnitteluun en pidä riittävänä).

Aikuiskoulutuksen kehittämisorganisaatio on tyypillinen esimerkki organisaatiosta, jossa 
sukupuolten tasa-arvoinen edustuksellisuus on jäänyt turvaamatta.

Aikuiskoulutuksen kehittämisorganisaatiota ei tosin voi syyttää miesenemmistöisestä kokoonpanostaan, koska se ei ole itse itseään nimittänyt. Tulee kuitenkin mieleen, olisikohan muistio ollut toisenlainen, jos sitä valmistavan johtoryhmän sukupuolirakenne olisi ollut päinvastainen!

Itse uskon, että sukupuolella on merkitystä niin suunnittelu - kuin toteutuspuolella. Oman sukupuolen käytöstä on helpompi ymmärtää, sillä esimerkiksi deprivoituminen, aktiivisuus, tuen tarve tai luovuus voivat ilmetä naisissa ja miehissä eri tavalla. Valitettavaa on, että johtoryhmän käyttöönsä tilaama, Tapio Vahervan laatima ihmiskuvamuistiokaan ei käsittele näitä asioita. Muistion ihmiskuva istuu sukupuolettomana enemmän miehelle kuin naiselle. Tämä ei puolestaan ole ihme, koska Vahervan lähdeluettelosta ei löydy ainuttakaan naisen kirjoittamaa ihmiskuvaanalyysia, vaikka naistutkimuksen piirissä on viime aikoina tuotettu runsaasti kriittistäkin alan kirjallisuutta.

\section{Joitakin päämääriä tasa- arvotavoitteelle aikuiskoulu- tuksessa}

\section{Yleissivistävän pohjakoulutustason kohottaminen}

Vähiten yleissivistävää ja ammatillista koulutusta saaneet aikuiset ovat suuri koulutusryhmä. Käytännössä ongelma on kasaantuva, vaikka uusien sukupolvien pohjakoulutustaso paranee jatkuvasti, sillä vähiten koulutusta saaneilla on pienimmät mahdollisuudet olla myös omien lastensa koulunkäynnin tukena. Koulujen ja kotien yhteistyössä heikoimmin menestyneiden lasten vanhemmat toimivat usein kaikkein passiivisimmin.

Aikuisväestön pohjakoulutustason kohottamissuunnittelu voisi lähteä esimerkiksi tämän tilanteen tunnistamisesta siten, että aikuisille ja kouluväelle järjestetään suoria ja tasa-arvoisia vuorovaikutustilanteita. Uudet koululait antanevat paikallistasolla lisää vapauksia opetussuunnitelmien laatimisessa. Aikuisopiskelijat voisivat antaa kouluviranomaisille näkemyksiä juuri kouluvaikeuksista tai -haluttomuudesta kärsivien oppilaiden kohdalla.

Aikuisopiskelijoiden opintosuunnitelma peruskoulun tai lukion suorittamiseksi voitaisiin tässä tapauksessa laatia esim. siten, että ensin olisi mahdollista kerrata ja pohtia oman ajan koulua: Mitä oman ajan koulussa ja elämässä oli sellaista, mikä vei opiskeluhalua. Uuden oppimiseen voisi vuorostaan kytkeä mm. seuraavia näkökulmia: Miten nykyinen koulu/opetussuunnitelma toistaa samoja virheitä? Mitä eväitä aikuisilla olisi omasta elämänkatsomuksestaan antaa tämän päivän koululle, koululaisille ja kasvatukselle yleensä?

Toinen kannustin yleissivistävän tietouden kohottamiseksi voisi olla käytännössä näkyvä arvostus sivistys- ja kulttuuriharrastuksia kohtaan. Esimerkiksi valittaessa henkilöitä kuntien ja valtion luottamustoimiin - alasta riippumatta - pidettäisiin huolta, että joukossa on riittävästi henkilöitä, joilla on näkemystä ja kokemusta kulttuuri- ja sivistysharrastuksista. Nykyinen "asiantuntija" -käsite ymmärretään niin kapeasti, että riman ylittävät usein vain ahkerimmat saunakaverit, joilla ei ole aikaa harrastaa muuta.

\section{Ammatillisesta koulutuksesta}

Ammatillista aikuiskoulutusta, uudelleenkoulutusta ja uraa edistävää koulutusta järjestetään niin työnantajien kuin yhteiskunnankin, valtion ja kuntien toimesta. Ammatillinen koulutus on useammin naisten kuin miesten ongelma ja ikäryhmittäin tarkasteltuna vanhimman väestönosan ongelma. Koko ammatillisen koulutuksen ongelma on sukupuolen mukaan eriytyneet koulutusalat siten, että vain $4 \%$ kaikista ammatillista koulutusta saaneista on saanut koulutusta aloille, jossa kumpaakin sukupuolta on suunnilleen yhtä paljon (40$60 \%$ ).

Ammatissa toimiminen on eriytynyt lähes yhtä jyrkästi. Työelämän jakautuminen naisten ja miesten töihin (sekä naisten ja miesten palkkatasoihin) näyttää olevan myös itseään täydentävää ja kiihtyvää, kuten Marja-Liisa Anttalaisen tasa-arvoasiain neuvottelukunnalle teettämästä tutkimuksesta on käynyt ilmi (Valtioneuvoston kanslian julkaisuja 1980:1).

Työelämä, joka ohjaa ihmisystävällisyyden, huolenpidon ja palvelualttiuden vain naisille sopivina pidetyille huolto-, hoito- ja palvelualoille, tukee maailmaa, jonka rakenteet ja elämisen ehdot ovat kovia ja epäinhimillisiä. Asuinalueiden suunnittelu, asuintalojen ja virastojen rakentaminen, liikenteenjärjestely, yhteisten asioiden hoito (politiikka) voi tapahtua henkilöiden toimesta, joilla ei ole omakohtaista tietoa jokapäiväisten asioiden hoitamisesta, ihmisten käyttäytymisestä tai inhimillisten kontaktien luonteesta.

Aikuisten maailma on malli nuorten valinnoille ja arvostuksille. Siksi yhtenä keskeisenä 
tavoitteena ammatillisessakin aikuiskoulutuksessa pitäisin kahtiajakautuneiden työmarkkinoiden murtamista: huolenpitoa ihmisestä teknistyvässä yhteiskunnassa sekä yleistä arvonantoa ja urallaetenemismahdollisuuksia naisvaltaisille hoito- ja palvelualoille.

\section{Koulutusta aikuisuuteen}

Tänä päivänä noin joka kuudes lapsiperhe on yksinhuoltajaperhe. Vuosittain solmitaan noin 30000 avioliittoa ja 10000 avioliittoa purkautuu. Yhden hengen ruokakuntia on yhtä paljon kuin "normaalina" pidettyjä neljän hengen ruokakuntia. Yhä useampi ihminen kokee elämänsä aikana monta eri vaihetta, vaikka olikin aikuisuuteen astuessaan suunnitellut ehkä vain yhtä yhdistelmää: työtä, perhettä ja lapsia.

Yksinäisyyteen tai yksinhuoltajuuteen ovat naiset saaneet paremmin valmennusta, ei tosin niinkään koulun vaan usein kantapään kautta: sukupuoleensa kohdistuvista rooliodotuksista tytöt imevät itseensä huonon omantunnon siivoamattomasta kodista, laittamattomista ruoista, poissaolostaan kotoa niin työn kuin iltaisten kokoustenkin ansiosta. Niinpä naisista kehittyy monitaitoisia, eri asioiden yhteensovit- tamiskykyisiä olentoja, joilla kuitenkin on tunne, etteivät ole riittävän hyviä. Kukaan ei myöskään kiitä kotona tehdystä työstä, koska ruoan lentäminen valmiina pöytään on muille perheenjäsenille itsestäänselvyys.

Koska naiset tottuvat puuhaamaan kotona, sovittamaan yhteen työ- ja vapaa-ajan ongelmia ja koska jopa monet naisten harrastukset (esim. lukeminen ja kutominen) sopivat kotitiloihin, ei yksinhuoltajuus tai oman olonsa viihtyisäksi tekeminen ole naisille niin iso ongelma kuin miehille.

Toivoisikin, että miesenemmistöinen aikuiskoulutuksen kehittämisorganisaatio käyttäisi nyt miehistä asiantuntemustaan: millä keinoin ja miten toteutettuna miehille voitaisiin järjestää koulutusta taidossa viihtyä ja tulla yksinkin toimeen. Tällainen taito kypsyttää ihmistä aivan toisella tavalla myös uusiin, tasaarvoisempiin ja muita huomioon ottaviin ihmissuhteisiin.

Sen sijaan naisten asiantuntemusta tarvittaisiin aikuiskoulutussuunnittelussa tavoitteessa, jonka tarkoituksena olisi kohottaa naisten itsetuntoa ja rohkeutta tuoda esiin ja puolustaa näkemyksiään yhteiskunnassa, jossa oikeana mittana on perinteisesti pidetty "miehen mittaa", pirstoutunutta ihmistä: nyt kun päätetään asioista, on tunteet jätettävä kotiin!? 